\title{
Marta BOROWSKA-STEFAŃSKA*
}

\section{DOSTĘPNOŚĆ TRANSPORTOWA OD JEDNOSTEK STRAŻY POŻARNYCH DO BUDYNKÓW ZLOKALIZOWANYCH NA TERENACH ZALEWOWYCH W POWIECIE ZDUŃSKOWOLSKIM}

\begin{abstract}
Streszczenie: W artykule za cel przyjęto ocenę dostępności transportowej z jednostek straży pożarnych do budynków zlokalizowanych na terenach zalewowych w powiecie zduńskowolskim. Do wyznaczania terenów zalewowych wykorzystano mapy zagrożenia powodziowego oraz dokumenty planistyczne, w tym studia uwarunkowań i kierunków zagospodarowania przestrzennego. Na tej podstawie dokonano identyfikacji obiektów zlokalizowanych na terenach zagrożonych powodziami, przy wykorzystaniu Bazy Danych Obiektów Topograficznych. Baza ta posłużyła również do lokalizacji jednostek straży pożarnych wpisanych do Krajowego Systemu Ratowniczo-Gaśniczego i wytypowanych do współpracy z systemem Państwowego Ratownictwa Medycznego, które znajdują się na obszarze analizowanego powiatu oraz gmin z nim bezpośrednio sąsiadujących. Stwierdzono, że w granicach terenów zalewowych badanych gmin znajduje się łącznie 514 budynków. Do 41 obiektów jest zapewniony dojazd z komend miejskich jednostek PSP w czasie do 8 minut oraz do 79 w czasie do 15 minut. W przypadku nadejścia powodzi do pozostałych budynków dojazd jest możliwy w czasie do 15 minut z jednostek OSP.
\end{abstract}

Słowa kluczowe: tereny zagrożone powodziami, straże pożarne, dostępność transportowa, OpenStreetMaps, GIS.

\section{DZIAŁALNOŚĆ JEDNOSTEK STRAŻY POŻARNEJ W TRAKCIE WYSTĄPIENIA POWODZI}

Ochrona przeciwpowodziowa należy do obowiązków publicznych, które muszą być realizowane zarówno przez jednostki administracji rządowej, jak i samorządowej, zgodnie z ustawą z dnia 18 lipca 2001 r. Prawo wodne ${ }^{1}$. Chodzi

* Marta Borowska-Stefańska, dr, adiunkt w Katedrze Zagospodarowania Środowiska i Polityki Przestrzennej, Wydział Nauk Geograficznych, Uniwersytet Łódzki, 90-142 Łódź, ul. Kopcińskiego 31.

${ }^{1}$ Ustawa z dnia 18 lipca 2001 r. Prawo wodne. 
przede wszystkim o normy prawne, procedury formalne i środki tworzenia warunków ochrony obywateli przed zjawiskami stwarzającymi niebezpieczeństwo zarówno dla zdrowia i życia, jak i majątku².

Ze względu na to, iż powódź to sytuacja kryzysowa, ma ona swoje odniesienie w ustawie z dnia 26 kwietnia 2007 r. o zarządzaniu kryzysowym ${ }^{3}$. Zgodnie z tą ustawą za sytuację kryzysową rozumie się ,stan narastającej destabilizacji powodujący intensywne, trwałe i długofalowe pogorszenie funkcjonowania społeczeństwa i państwa, charakteryzujące się eskalacją zagrożenia, a w konsekwencji często utratą kontroli nad ograniczaniem skutków zdarzenia przez poszczególne służby, inspekcje lub straże".

Zarządzanie powodziowe wpisuje się w zarządzanie kryzysowe, które oznacza zespół uporządkowanych, planowych działań i przedsięwzięć, których celem jest zapobieganie sytuacjom kryzysowym, odpowiednie nimi kierowanie poprzez kształtowanie ich przebiegu i kontrolę, a w konsekwencji ograniczenie strat oraz odtworzenie zasobów lub przywrócenie im pierwotnego charakteru. System zarządzania kryzysowego dotyczy sytuacji wystąpienia zagrożeń wymagających podjęcia szczególnych działań ze strony administracji publicznej. Może być ono stosowane w przypadku wydarzeń naturalnych, w tym również powodzi, zgodnie z zapisami ustawy z dnia 18 kwietnia 2002 r. o stanie klęski żywiołowej ${ }^{4}$.

Ustawa o stanie klęski żywiołowej w art. 17. ust. 1. na pierwszym miejscu wśród służb i urzędów, które zobowiązuje się do zapobiegania ich skutkom, wymienia Państwową Straż Pożarną i inne jednostki ochrony przeciwpożarowej oraz centra powiadamiania ratunkowego. Państwowa Straż Pożarna i pozostałe służby, straże, urzędy, policja podlegają kierownictwu wójta/burmistrza/prezydenta, starosty lub wojewody, ministra właściwego do spraw administracji publicznej lub innego w zależności od obszaru objętego stanem klęski ${ }^{5}$.

$\mathrm{Na}$ obszarze powiatu organem właściwym w sprawach zarządzania kryzysowego jest starosta, jako przewodniczący zarządu powiatu. W przypadku gminy obowiązki związane z zapewnieniem bezpieczeństwa na swoim obszarze spełnia wójt, burmistrz, prezydent miasta ${ }^{6}$.

2 M. Bac, Tradycja i innowacje w zarzadzaniu ryzykiem powodziowym w Polsce, „Zeszyty Naukowe Małopolskiej Wyższej Szkoły Ekonomicznej w Tarnowie” 2011, nr 19, s. 23.

${ }^{3}$ Ustawa z dnia 26 kwietnia 2007 r. o zarządzaniu kryzysowym (Dz.U. 2007, Nr 89, poz. 590, $\mathrm{z}$ późn. zm.).

${ }^{4}$ M. Bac, Zarzadzanie kryzysowe $w$ organizacjach $w$ kontekście polskiego ustawodawstwa, „Zeszyty Naukowe Małopolskiej Wyższej Szkoły Ekonomicznej w Tarnowie” 2009, Nr 2, s. 10-12.

${ }^{5}$ P. Suchorab, Akty prawne regulujace problemy klęsk żywiołowych, [w:] Doraźne metody ochrony stosowane podczas powodzi ze szczególnym uwzględnieniem rękawów przeciwpowodziowych, red. D. Riegert, Centrum Naukowo-Badawcze Ochrony Przeciwpożarowej im. J. Tuliszkowskiego PIB, Józefów 2012, s. 132.

${ }^{6}$ T.Z. Leszczyński, Kluczowe zadania administracji samorzadowej w zarzadzaniu kryzysowym, [w:] Bezpieczeństwo i Zarządzanie kryzysowe - aktualne wyzwania. Zarządzanie bezpieczeństwem w sektorze publicznym, red. M. Włodarczyk, A. Marjański, „Przedsiębiorczość i Zarządzanie” 2009, t. X, z. 8, s. 73-75. 
Straż pożarna jest służbą wiodącą, jeśli chodzi o prowadzenie działań powodziowych. „Trzon działań ratowniczych stanowią jednostki włączone do Krajowego Systemu Ratowniczo-Gaśniczego. Do głównych zadań jednostek PSP oraz OSP należy przede wszystkim:

- ewakuacja ludzi z zagrożonych terenów, budynków mieszkalnych, budynków użyteczności publicznej itp.,

- ewakuacja inwentarza i dobytku materialnego,

- dostarczanie powodzianom wody, żywności, lekarstw oraz innych środków pierwszej pomocy,

- usypywanie, umacnianie i uszczelnianie wałów przeciwpowodziowych,

- udrażnianie rzek, przepustów, mostów poprzez usuwanie wszelkich zalegających materiałów ograniczających ich przepustowość,

- wypompowywanie wody z zalanych budynków mieszkalnych, gospodarczych, użyteczności publicznej i terenów zalanych,

- wszelkie inne czynności, których wykonanie usprawnia lub przyspiesza cały cykl działań ratowniczych (przyjmowanie i przekazywanie informacji o zdarzeniach, oznakowanie i zabezpieczenie miejsca prowadzonych działań, oświetlenie terenu akcji ratunkowej, zasilanie budynków, urządzeń w energię elektryczną i in.). W akcji powodziowej straż pożarna wykorzystuje wszelki dostępny sprzęt znajdujący się na wyposażeniu jednostek, który jest użyteczny podczas działań ratowniczych"?.

Czas dojazdu jednostek straży pożarnej na miejsce zdarzenie ma bezpośredni wpływ na ratowanie zdrowia i życia ludzi, a także skuteczność prowadzonych działań ratowniczych ${ }^{8}$. Zgodnie z Rozporządzeniem Ministra Spraw Wewnętrznych i Administracji z dnia 18 lutego 2011 r. wszystkie podmioty zlokalizowane z mieście, gminie czy powiecie, włączone do Krajowego Systemu Ratowniczo-Gaśniczego (KSRG), realizują podstawowe czynności ratownicze w obszarze swojego działania określone czasem dojazdu: do 8 i do 15 minut. W sytuacji, gdy jednostki Państwowej Straży Pożarnej nie są w stanie dotrzeć w czasie do 15 minut, dojazd pierwszych sił i środków na miejsce zdarzenie (w tym przypadku do obiektów zlokalizowanych na terenach zalewowych) powinien być zapewniony przez jednostki Ochotniczej Straży Pożarnej (OSP) włączone do KSRG9.

7 Plan operacyjny ochrony przed powodzią dla województwa łódzkiego 2013, s. 20.

${ }^{8}$ S. Krawczyńska, T. Drzymała, J. Gałaj, Badanie wpływu różnych czynników na czas interwencji jednostek PSP w czasie działań ratowniczo-gaśniczych, „Logistyka” 2014, 5, s. 832.

${ }_{9}$ T. Drzymała, S. Krawczyńska, J. Gałaj, Badanie wpływu różnych czynników na czas dojazdu samochodów ratowniczo-gaśniczych z siedziby jednostki PSP na miejsce akcji, „Logistyka” 2014, 4, s. 230. 


\section{CHARAKTERYSTYKA OBSZARU BADAŃ I METODOLOGIA}

Celem pracy było określenie czasu dojazdu od jednostek straży pożarnych (jednostek PSP oraz OSP wpisanych do KSRG oraz wytypowanych do współpracy z systemem Państwowego Ratownictwa Medycznego, położonych w granicach powiatu zduńsko-wolskiego oraz gmin sąsiednich) do budynków zlokalizowanych na terenach zagrożonych powodziami $\mathrm{w}$ gminach powiatu zduńskowolskiego ${ }^{10}$.

Analizowany obszar położony jest w dorzeczu Odry, w zlewni Warty (ryc. 1), której długość w granicach województwa łódzkiego wynosi ok. $200 \mathrm{~km}$. Jej dolina ma zmienny charakter, jest częściowo obwałowana ${ }^{11}$. Warta płynie w południowo-zachodniej części badanego powiatu, stanowi jednocześnie granicę gminy Zapolice. Ponadto sieć rzeczną na tym obszarze tworzą rzeki: Widawka, Pichna, Pisia, Brodnia, Tymianka i Grabia ${ }^{12}$.

W przypadku gminy Zapolice tereny zagrożone powodziami zostały wyznaczone na podstawie map zagrożenia powodziowego (zarówno tereny szczególnego, jak i potencjalnego zagrożenia powodzią), które opublikowano na koniec 2013 r. ${ }^{13} \mathrm{~W}$ gminie, a także mieście Zduńska Wola oraz w gminie Szadek zasięg terenów zalewowych określono na podstawie studiów uwarunkowań i kierunków zagospodarowania przestrzennego, gdyż dla mniejszych rzek, mapy zagrożenia powodziowego nie zostały opracowane.

Tereny zagrożone powodziami zajmują największą powierzchnię w gminie Zapolice (rzeka Warta i Widawka) - łącznie 1550,4 ha, z czego na tereny szczególnego zagrożenia powodzią przypada 911,66 ha, zaś na tereny potencjalnego zagrożenia - 638,74 ha. Rzeka Warta oraz Widawka zostały na znacznej długości obwałowane. Długość wałów lewobrzeżnych Warty wynosi - 13,25 km, prawobrzeżnych - 10,17 km, lewobrzeżnych rzeki Widawki - 2,1 km, zaś prawobrzeżnych rzeki Widawki - 3,9 $\mathrm{km}^{14}$. W gminie Szadek tereny zalewowe zajmują powierzchnię 978,8 ha, z czego 251,9 ha to tereny wzdłuż Pisi, 583,2 ha - tereny wzdłuż Pichny oraz 143,7 ha - tereny zalewowe nad Brodnią. W gminie Zduńska Wola tereny zagrożone powodziami położone nad Pichną zajmują powierzchnię 340,63 ha, zaś w granicach miasta Zduńska Wola zaledwie 14 ha (ryc. 2).

${ }^{10} \mathrm{~W}$ przypadku analiz nie ograniczono się jedynie do straży pożarnych w powiecie zduńskowolskim, gdyż tereny zagrożone powodziami, m.in. w Zapolicach, są na granicy z gminami Widawa, Burzenin, Sieradz. Przyjęto założenie, że do tych obszarów dojazd w sytuacji wystąpienia powodzi może zostać zapewniony również z jednostek straży zlokalizowanych w gminach sąsiednich i do analiz włączono, poza jednostkami z powiatu zduńskowolskiego, również te, które są w gminach bezpośrednio z nim sąsiadujących.

${ }^{11}$ Wojewódzki program małej retencji dla województwa łódzkiego, 2005, s. 29; M. Borowska-Stefańska, Zagospodarowanie terenów zagrożonych powodziami w województwie tódzkim, Wydawnictwo Uniwersytetu Lódzkiego 2015, s. 39.

12 Plan rozwoju Miejskiego Obszaru Funkcjonalnego Zduńska Wola-Karsznice na lata 20142020, s. 28.

${ }^{13} \mathrm{http}: / /$ mapy.isok.gov.pl/imap/ [dostęp 20.01.2016].

${ }^{14}$ Informacje pozyskane z WZMiUW w Łodzi. 


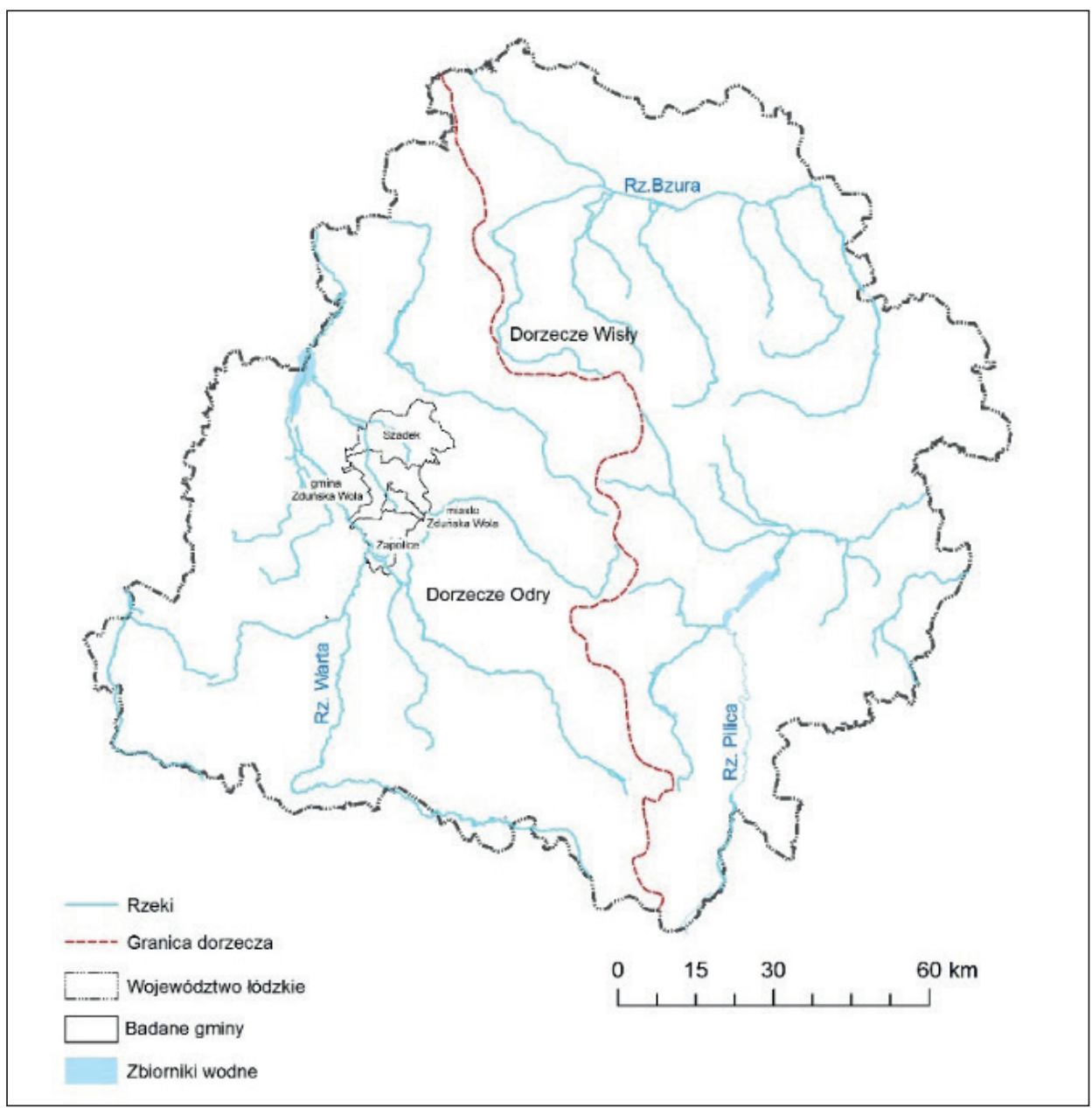

Ryc. 1. Sieć rzeczna województwa łódzkiego i położenie powiatu zduńskowolskiego Źródło: opracowanie własne, 2016

W kolejnym etapie dokonano identyfikacji budynków, znajdujących się w granicach terenów zagrożonych powodziami, przy wykorzystaniu Bazy Danych Obiektów Topograficznych. Do dalszych analiz wzięto tylko te obiekty, które w znacznej części mieściły się w granicach terenów zalewowych.

Następnie przy wykorzystaniu narzędzia do analiz sieciowych w programie ArcGiS zbadano dostępność transportową od jednostek straży pożarnych, zlokalizowanych w powiecie zduńskowolskim i gminach bezpośrednio sąsiadujących, do budynków znajdujących się na badanych obszarach. Dostępność 


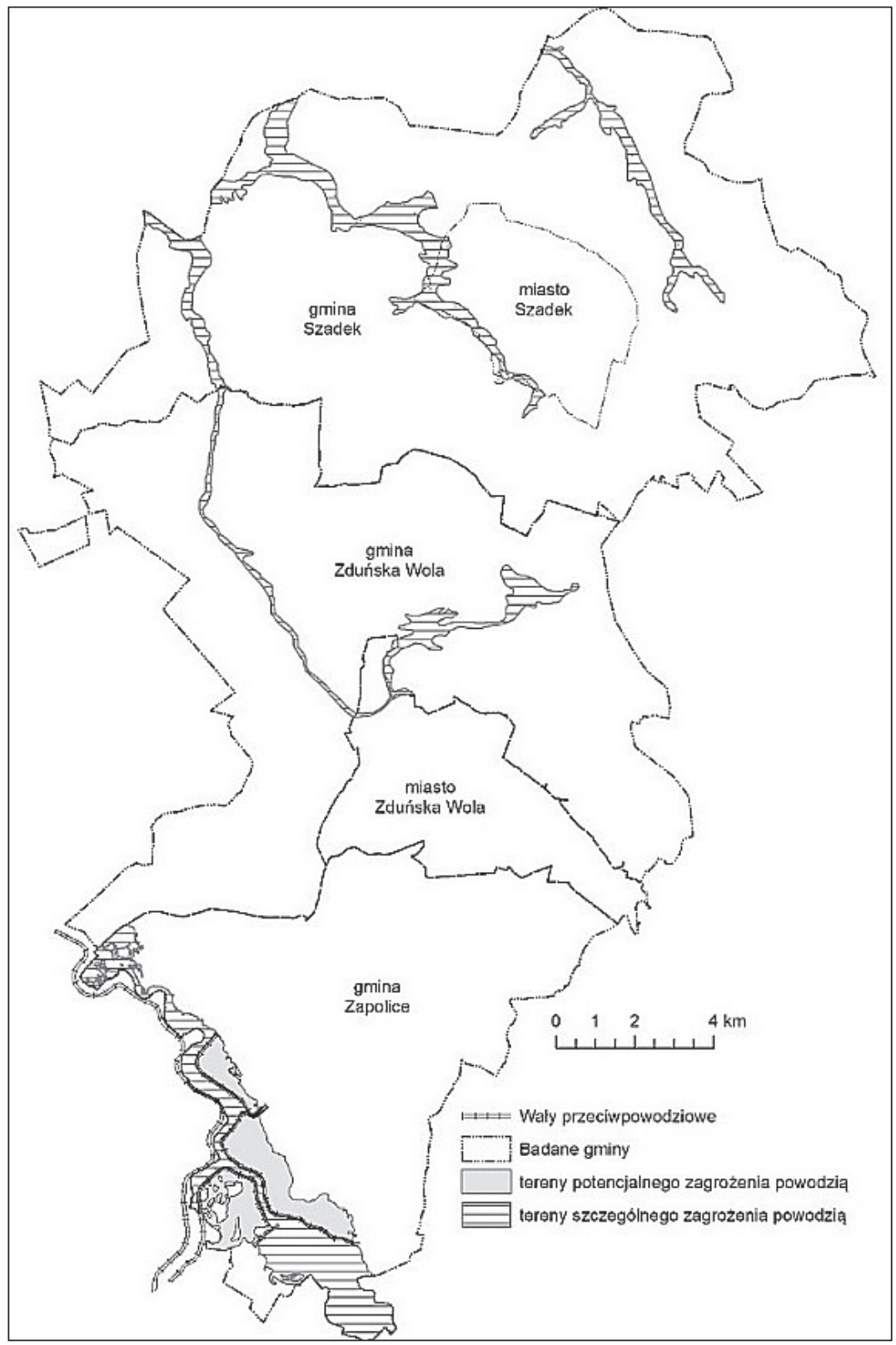

Ryc. 2. Tereny zalewowe $\mathrm{w}$ gminach powiatu zduńskowolskiego

Źródło: opracowanie własne na podstawie: http://mapy.isok.gov.pl/imap/ [dostęp 20.01.2016] oraz Studium uwarunkowań i kierunków zagospodarowania miasta i gminy Szadek 2012, Studium uwarunkowań i kierunków zagospodarowania przestrzennego miasta Zduńska Wola 2012, Studium uwarunkowań i kierunków zagospodarowania przestrzennego gminy Zduńska Wola 2013 
to jedno z podstawowych pojęć z zakresu nauk społecznych, w szczególności w geografii społeczno-ekonomicznej, gospodarce przestrzennej i ekonomii ${ }^{15}$. Ważne dla artykułu są również pojęcia dostępności przestrzennej i transportowej. Dostępność przestrzenna oznacza „łatwość osiągnięcia miejsca lub funkcji z innego miejsca/miejsc wyrażona dystansem do pokonania, kosztem transportu bądź czasem podróży ${ }^{16}$. „Dostępność komunikacyjna (transportowa) to pojęcie szersze niż dostępność przestrzenna - oprócz dostępności komunikacyjnej określonego punktu, czy miasta (wówczas jest zbieżna z dostępnością przestrzenną) obejmuje swoim znaczeniem dostępność komunikacyjną obszaru, rozumianą jako jego drożność, a także dostępność sieci komunikacyjnej" ${ }^{\prime 17}$.

W artykule za miarę dostępności przyjęto czas dojazdu samochodem strażackim do budynków znajdujących się na terenach zagrożonych powodziami. Wynikiem analiz było przedstawienie liczby budynków (oraz zajmowanej przez nie powierzchni) zlokalizowanych $\mathrm{w}$ izochronach $0-8$ minut; $8-15 \mathrm{mi}$ nut od jednostek straży pożarnych. W pierwszej kolejności analizie poddano dostępność od komend powiatowych/miejskich Państwowej Straży Pożarnej (PSP), a następnie od jednostek ochotniczych straży pożarnych, wpisanych do KSRG oraz wytypowanych do współpracy z systemem Państwowego Ratownictwa Medycznego, co ma istotne znaczenie dla ratowania ludności z zagrożonych miejsc. W powiecie zduńskowolskim i gminach z nim bezpośrednio sąsiadujących zinwentaryzowano 2 jednostki powiatowe PSP oraz 26 OSP (ryc. 3).

Do badań wykorzystano m.in. dane pochodzące z zasobu OpenStreetMap $(\mathrm{OSM})^{18}$. Projekt ten został zainicjowany przez Steve'a Coasta, który chciał stworzyć wolną i otwartą mapę świata, z możliwością jej edycji ${ }^{19}$. Drogi zostały wprowadzone do bazy jako liniowe. Dla obliczeń czasu przejazdu od jednostek straży pożarnych przyjęto dopuszczalne prędkości przejazdowe w zależności od kategorii drogi (tabl. 1).

${ }^{15} \mathrm{~S}$. Wiśniewski, Zróżnicowanie dostępności transportowej miast $w$ województwie łódzkim, Wydawnictwo Uniwersytetu Łódzkiego 2015, s. 17.

${ }^{16}$ R. Guzik, Przestrzenna dostępność szkolnictwa ponadpodstawowego w województwie matopolskim, Kraków 2001, s. 34.

17 Tamże, s. 35.

${ }^{18}$ M. Borowska-Stefańska, Dostępność transportowa od straży pożarnych do obiektów spotecznych zlokalizowanych na terenach zagrożonych powodziami w województwie łódzkim z wykorzystaniem analiz sieciowych, „Transport Miejski i Regionalny” 2016, nr 3, s. 30; http://download. geofabrik.de/europe/poland/ lodzkie.html [dostęp 01.12.2015].

19 P. Drop, P. Gajewski, M. Mackiewicz, Zastosowanie danych OPENSTREETMAP oraz wolnego oprogramowania do badań dostęności komunikacyjnej w skali lokalnej, „Acta Univesitatis Lodziensis. Folia Geographica Socio-Oeconomica” 2013, 14, s. 158. 


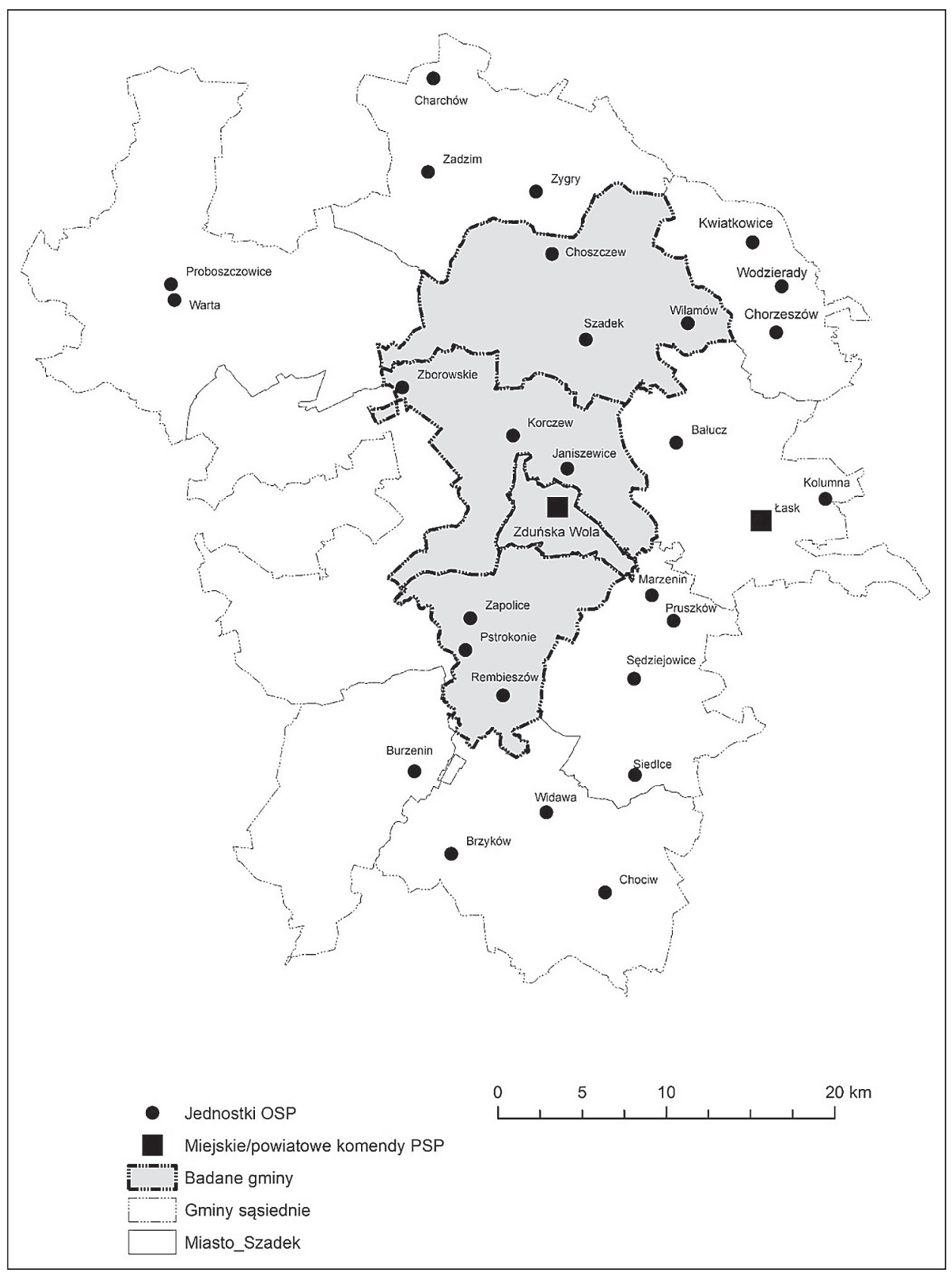

Ryc. 3. Rozmieszczenie jednostek straży pożarnych wpisanych do KSRG i wytypowanych do współpracy z systemem państwowego ratownictwa medycznego w powiecie zduńskowolskim i gminach sąsiadujących Źródło: opracowanie własne, 2016 
Tablica 1. Klasyfikacja dróg w OpenStreetMaps wraz z dopuszczalnymi prędkościami przejazdowymi

\begin{tabular}{|c|c|}
\hline Klasyfikacja drogi w OSM & Prędkość $(\mathbf{k m} / \mathbf{h})$ \\
\hline Motorway - autostrada & 140 \\
\hline Trunk - droga ekspresowa & 120 \\
\hline Primary - droga krajowa (w Polsce) & 90 \\
\hline Secondary - droga wojewódzka (w Polsce) & 90 \\
\hline Tertiary - powiatowa (w Polsce) & 50 \\
\hline Unclassified - gminna (w Polsce) & 50 \\
\hline Residential - droga osiedlowa & 20 \\
\hline Living street - droga w strefie zamieszkania & 20 \\
\hline Track - droga gruntowa & 20 \\
\hline
\end{tabular}

Źródło: opracowano na podstawie Drop i in. 2013.

Analizy przeprowadzono dla powiatu zduńskowolskiego, jednak dla prawidłowego wyznaczenia czasu przejazdu stworzono bufor od granic powiatu i gmin z nim bezpośrednio sąsiadujących o odległości $2 \mathrm{~km}$ i dla tego obszaru wyeksportowano drogi. Następnie przy pomocy narzędzia do analiz sieciowych dokonano w programie GIS obliczeńn ${ }^{20}$.

\section{WYNIKI}

W granicach terenów zalewowych powiatu zduńskowolskiego znajduje się łącznie 514 budynków. Prawie połowa zabudowań zlokalizowana jest w gminie Zapolice - 243 budynki (241 na terenach potencjalnego zagrożenia powodzią - położonych poza wałami), na kolejnym miejscu jest Szadek - 214 budynków. W gminie Zduńska Wola oraz w granicach miasta Zduńska Wola na analizowanych obszarach znajduje się odpowiednio 32 i 25 zabudowań. Na obszarach zalewowych w gminach podlegających badaniu najwięcej jest budynków gospodarczych - 272, które towarzyszą obiektom mieszkalnym - 166 (tabl. 2).

W pierwszym etapie analizie poddano liczbę budynków w izochronach $0-8 \mathrm{mi}-$ nut oraz 8-15 minut od komend powiatowych/miejskich Państwowej Straży Pożarnej. Stwierdzono, że łącznie do 41 budynków (25 zlokalizowanych w Zduńskiej Woli i 16 z obszaru gminy Zduńska Wola) zapewniony jest dojazd w czasie do 8 minut, natomiast do 79 obiektów (12 z gminy Zduńska Wola, 67 z gminy Szadek - teren zalewowy Pichny) można dojechać w czasie 8-15 minut (ryc. 4).

${ }^{20}$ Ze względu na to, że do analiz wzięto jednostki straży pożarnych, przy analizach nie stosowano żadnych ograniczeń, gdyż pojazdy straży pożarnych są uprzywilejowane. 
Tablica 2. Funkcje budynków zlokalizowanych na terenach zagrożonych powodziami w powiecie zduńskowolskim

\begin{tabular}{|c|c|c|c|c|c|c|c|c|}
\hline \multirow{2}{*}{$\begin{array}{c}\text { Funkcja } \\
\text { budynków }\end{array}$} & \multicolumn{3}{|c|}{ Szadek } & \multirow{2}{*}{$\begin{array}{c}\text { Zduńska } \\
\text { Wola } \\
\text { - gmina } \\
\text { wiejska }\end{array}$} & \multirow{2}{*}{$\begin{array}{c}\begin{array}{c}\text { Zduńska } \\
\text { Wola - } \\
\text { miasto }\end{array} \\
\text { Pichna }\end{array}$} & \multicolumn{2}{|c|}{$\begin{array}{l}\text { Zapolice } \\
\text { - tereny }\end{array}$} & \multirow{2}{*}{ Suma } \\
\hline & Brodnia & Pichna & Pisia & & & $\begin{array}{c}\text { wody } \\
1 \%\end{array}$ & $\begin{array}{c}\text { zagrożenia } \\
\text { powodzią }\end{array}$ & \\
\hline $\begin{array}{l}\text { Budynki } \\
\text { mieszkalne }\end{array}$ & 5 & 56 & 18 & 13 & 10 & - & 64 & 166 \\
\hline $\begin{array}{l}\text { Budynki } \\
\text { usługowe }\end{array}$ & - & 3 & 1 & - & - & - & 2 & 6 \\
\hline $\begin{array}{l}\text { Budynki } \\
\text { przemysłowo- } \\
\text {-magazynowe }\end{array}$ & - & 10 & - & - & - & - & - & 10 \\
\hline $\begin{array}{l}\text { Budynki go- } \\
\text { spodarcze }\end{array}$ & 13 & 65 & 41 & 18 & 15 & - & 120 & 272 \\
\hline $\begin{array}{l}\text { Budynki } \\
\text { letniskowe }\end{array}$ & - & - & 1 & 1 & - & 2 & 55 & 59 \\
\hline $\begin{array}{l}\text { Obiekty } \\
\text { infrastruktury } \\
\text { technicznej }\end{array}$ & - & - & 1 & - & - & - & - & 1 \\
\hline Suma & 18 & 134 & 62 & 32 & 25 & 2 & 241 & 514 \\
\hline
\end{tabular}

Źródło: opracowanie własne na podstawie BDOT, 2016.

Do pozostałych $77 \%$ budynków zlokalizowanych na terenach zalewowych w przypadku nadejścia powodzi należy zapewnić dojazd pierwszych sił i środków poprzez włączone do krajowego systemu ratowniczo-gaśniczego (oraz współpracujące z systemem państwowego ratownictwa medycznego) jednostki Ochotniczych Straży Pożarnych (OSP).

W wyniku włączenia do analiz jednostek OSP stwierdzono, że do 327 budynków zapewniony jest dojazd w czasie do 8 minut. W głównej mierze są one zlokalizowane na terenie potencjalnego zagrożenia powodzią w Zapolicach - 232 budynki. Ponadto 89 obiektów znajduje się na terenie zalewowym w gminie Szadek (25 wzdłuż Pichny, 61 wzdłuż Pisi oraz 3 nad Brodnią). W czasie do 8 minut zapewniony jest również czas dojazdu do budynków zlokalizowanych na obszarze zagrożonym powodzią w gminie Zduńska Wola -4 obiekty oraz 2 w zasięgu tzw. wody 100-letniej gminy Zapolice. Do 73 budynków, w sytuacji wystąpienia powodzi, możliwe jest dotarcie służb z jednostek OSP w czasie 8-15 minut (71 zlokalizowanych jest w Szadku: 15 nad Brodnią, 55 nad Pichną, 1 nad Pisią; 1 w gminie Zduńska Wola i 1 w Zapolicach w zasięgu tzw. wody 100-letniej) (rys. 5). 


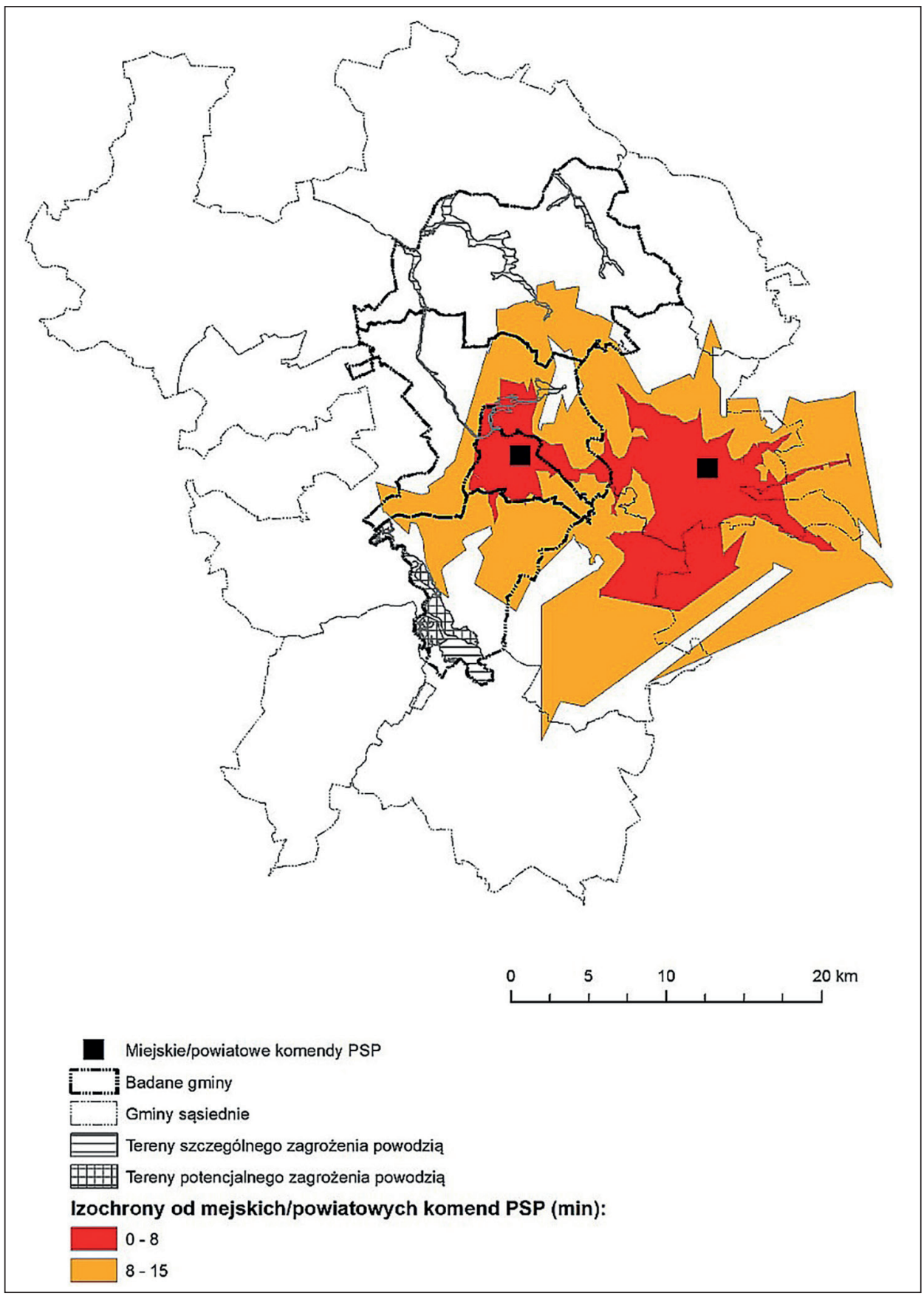

Ryc. 4. Izochrony od komend miejskich PSP w Łasku i Zduńskiej Woli Źródło: opracowanie własne, 2016 


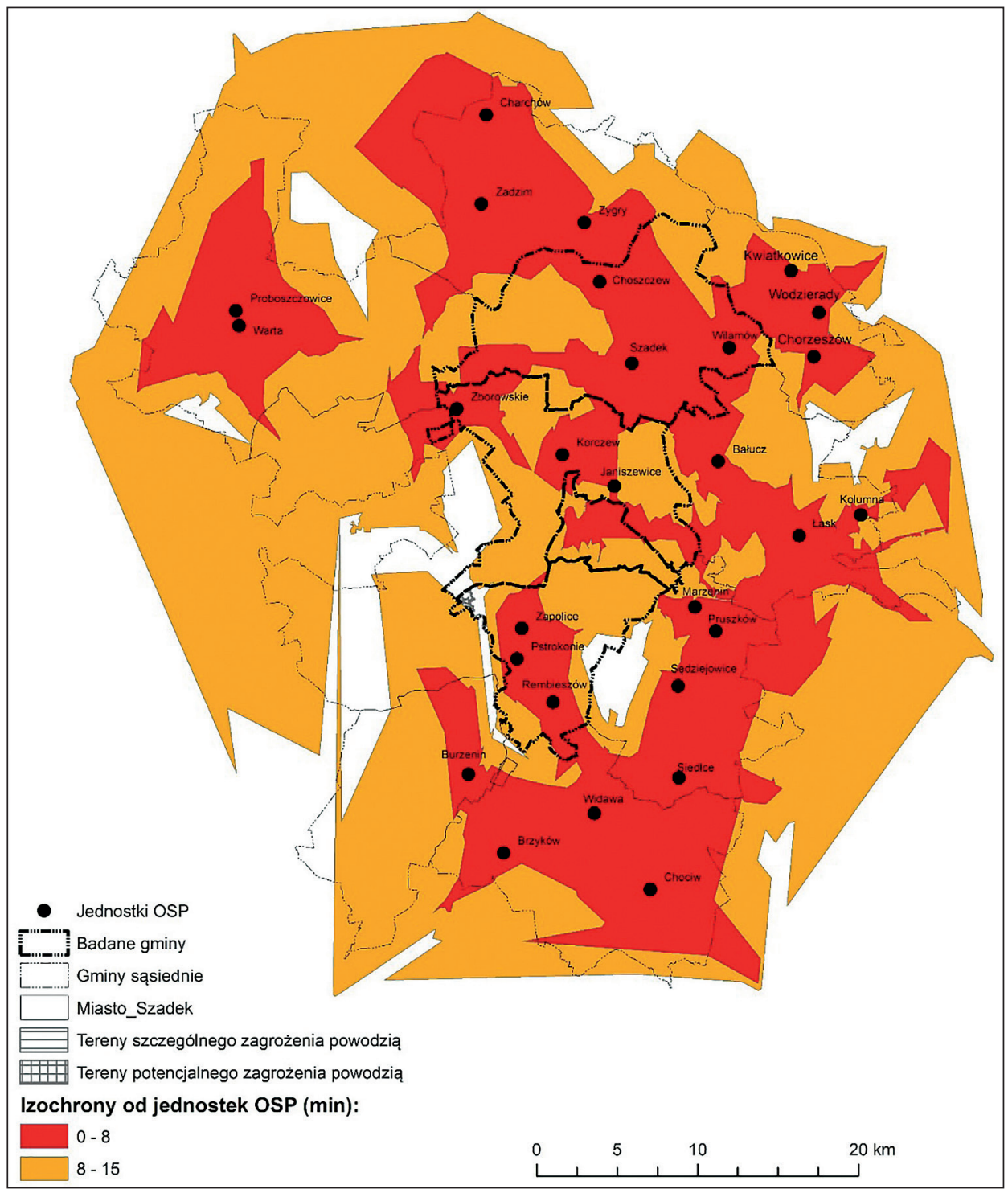

Rys. 5. Izochrony od jednostek OSP zlokalizowanych w powiecie zduńskowolskim oraz gminach sąsiednich

Źródło: opracowanie własne, 2016

Analizując zarówno czas dojazdu z komend miejskich PSP, jak i z jednostek OSP, należy stwierdzić, że w przypadku wystąpienia powodzi na obszarze powiatu zduńskowolskiego do wszystkich budynków zlokalizowanych w granicach terenów zalewowych zapewniony jest dojazd w czasie do 15 minut. Ma to bardzo 
istotne znaczenie, gdyż tylko wówczas ,istnieje możliwość podjęcia skutecznych działań, a co ważniejsze możliwość skutecznego udzielenia pomocy osobom poszkodowanym"21.

\section{WNIOSKI}

Dzięki zastosowaniu analiz sieciowych możliwe było określenie dostępności transportowej z jednostek straży pożarnych do budynków zlokalizowanych na terenach zalewowych, w gminach powiatu zduńskowolskiego. Uzyskane wyniki analiz mogą być pomocne $\mathrm{w}$ prowadzeniu polityki w zakresie ochrony przeciwpowodziowej, a także mogą zostać wykorzystane przy lokalizacji nowych jednostek PSP lub OSP.

W wyniku przeprowadzonych badań stwierdzono, że do wszystkich budynków zlokalizowanych na terenach zagrożonych powodziami w badanych gminach, czas dojazdu z jednostek PSP oraz OSP nie przekracza 15 minut. Do 3/4 obiektów pomoc zapewniona jest dzięki odpowiedniej lokalizacji jednostek OSP wpisanych do krajowego systemu ratowniczo-gaśniczego i współpracujących z systemem państwowego ratownictwa medycznego. Ma to istotne znaczeniu, gdyż w tym właśnie czasie ,istnieje możliwość podjęcia skutecznych działań, a co ważniejsze możliwość skutecznego udzielenia pomocy osobom poszkodowanym"22.

W przypadku gminy Szadek, czas dojazdu z jednostek PSP do 67 obiektów znajdujących się w granicach terenów zalewowych Pichny wynosi 8-15 minut. Do pozostałych zabudowań (147), położonych na terenach zagrożonych powodziami gminy Szadek, czas dojazdu do 15 minut jest zapewniony z jednostek OSP, które na tym obszarze, w sytuacji kryzysowej, odgrywają kluczową rolę.

\section{Bibliografia}

Bac M., Zarzadzanie kryzysowe w organizacjach w kontekście polskiego ustawodawstwa, „Zeszyty Naukowe Małopolskiej Wyższej Szkoły Ekonomicznej w Tarnowie” 2009, nr 2, s. 9-21.

Bac M., Tradycja i innowacje w zarzadzaniu ryzykiem powodziowym w Polsce, „Zeszyty Naukowe Małopolskiej Wyższej Szkoły Ekonomicznej w Tarnowie" 2011, nr 19, s. 21-32.

Baza Danych Obiektów Topograficznych, Wojewódzki Ośrodek Dokumentacji Geodezyjnej i Kartograficznej w Lodzi, 2015.

Borowska-Stefańska M., Zagospodarowanie terenów zagrożonych powodziami w województwie tódzkim, Wydawnictwo Uniwersytetu Łódzkiego, Łódź 2015.

${ }^{21}$ T. Drzymała, S. Krawczyńska, J. Gałaj, Badanie wplywu..., s. 230.

22 Tamże. 
Borowska-Stefańska M., Dostępność transportowa od straży pożarnych do obiektów spotecznych zlokalizowanych na terenach zagrożonych powodziami w województwie tódzkim z wykorzystaniem analiz sieciowych, ,Transport Miejski i Regionalny”2016, nr 3, s. 28-32.

Drop P., Gajewski P., Mackiewicz M., Zastosowanie danych OPENSTREETMAP oraz wolnego oprogramowania do badań dostęności komunikacyjnej w skali lokalnej, „Acta Univesitatis Lodziensis. Folia Geographica Socio-Oeconomica" 2013, 14, s. 157-167.

Drzymała T., Krawczyńska S., Galaj J., Badanie wpływu różnych czynników na czas dojazdu samochodów ratowniczo-gaśniczych z siedziby jednostki PSP na miejsce akcji, „Logistyka” 2014, nr 4, s. 230-237.

Guzik R., Przestrzenna dostępność szkolnictwa ponadpodstawowego w województwie małopolskim, Kraków 2001.

Informacje pozyskane z WZMiUW w Łodzi.

Krawczyńska S., Drzymała T., Gałaj J., Badanie wpływu różnych czynników na czas interwencji jednostek PSP w czasie działań ratowniczo-gaśniczych, „Logistyka” 2014, 5, s. 832-841.

Leszczyński T.Z., Kluczowe zadania administracji samorzadowej w zarządzaniu kryzysowym, [w:] Bezpieczeństwo i Zarzadzanie kryzysowe - aktualne wyzwania. Zarzadzanie bezpieczeństwem w sektorze publicznym, red. M. Włodarczyk, A. Marjański, „Przedsiębiorczość i Zarządzanie" 2009, t. X, z. 8, s. 69-78.

Plan operacyjny ochrony przed powodzia dla województwa łódzkiego 2013.

Plan rozwoju Miejskiego Obszaru Funkcjonalnego Zduńska Wola-Karsznice na lata 2014-2020.

Rozporządzenie Ministra Spraw Wewnętrznych i Administracji z dnia 18 lutego $2011 \mathrm{r}$. w sprawie szczegółowych zasad organizacji krajowego systemu ratowniczo-gaśniczego.

Studium uwarunkowań i kierunków zagospodarowania miasta i gminy Szadek 2012.

Studium uwarunkowań i kierunków zagospodarowania przestrzennego miasta Zduńska Wola 2012.

Studium uwarunkowań i kierunków zagospodarowania przestrzennego gminy Zduńska Wola 2013.

Suchorab P., Akty prawne regulujace problemy klęsk żywiolowych, [w:] Doraźne metody ochrony stosowane podczas powodzi ze szczególnym uwzględnieniem rękawów przeciwpowodziowych, red. D. Riegert, Centrum Naukowo-Badawcze Ochrony Przeciwpożarowej im. Józefa Tuliszkowskiego PIB, Józefów 2012, s. 110-142.

Ustawa z dnia 26 kwietnia 2007 r. o zarządzaniu kryzysowym (Dz.U. 2007, Nr 89, poz. 590 , z późn. zm.)

Ustawa z dnia 18 lipca 2001 r. Prawo wodne.

Wiśniewski S., Zróżnicowanie dostępności transportowej miast w województwie tódzkim,

Wydawnictwo Uniwersytetu Łódzkiego, Łódź 2015.

Wojewódzki program małej retencji dla województwa łódzkiego, 2005.

\section{Strony internetowe}

http://mapy.isok.gov.pl/imap/ [dostęp 20.01.2016].

http://download.geofabrik.de/europe/poland/lodzkie.html [dostęp 01.12. 2015].

[Wpłynęło: marzec; poprawiono: czerwiec 2016 r.] 


\title{
TRANSPORT ACCESSIBILITY FROM FIREFIGHTERS TO OBJECTS LOCATED WITHIN FLOOD HAZARD AREAS IN THE DISTRICT OF ZDUŃSKA WOLA
}

\begin{abstract}
Summary
The goal of this article is to assess transport accessibility from fire brigades to objects located within the flood hazard zone in the district of Zduńska Wola. To determine the areas exposed to floods, flood hazard maps and planning documents were used, including the study of the conditions and directions of spatial development. On this basis, the objects located within areas exposed to floods were identified, using the Topographic Objects Database. This database was also used to locate the fire brigade units, operating within the National Rescue and Firefighting System in the analyzed district and neighboring municipalities. To carry out the analysis of the transport accessibility, data from OpenStreetMap (OSM) and a tool for network analysis in the ArcGis were employed. It was found that within the flood hazard areas in the surveyed municipalities are 514 buildings. 41 of these objects can be accessed from the municipal units of the fire brigade in up to 8 minutes, and 79 buildings can be reached in up to 15 minutes. In the case of flood, the remaining buildings can be reached in up to 15 minutes from the voluntary fire brigades.
\end{abstract}

Keywords: flood hazard zone, firefighters, transport accessibility, OpenStreetMaps, GIS. 